\title{
荷重伝達型片側すみ肉溶接構造物における疲労き裂進展挙動の観察
}

\author{
阿部 孝正 ${ }^{* 1}$ ，曙 紘之 ${ }^{* 2}$ \\ 加藤 昌彦 ${ }^{* 2}$, 菅田 淳*2
}

\section{3-Dimensional observation on the fatigue crack propagation behaviour of the structures with one-sided welding of the fillet joint for load carrying type}

\author{
Takamasa $\mathrm{ABE}^{* 1}$, Hiroyuki AKEBONO ${ }^{* 2}$, \\ Masahiko KATO $^{* 2}$ and Atsushi SUGETA ${ }^{* 2}$ \\ ${ }^{* 1}$ Kobelco Construction Machinery CO.,LTD. \\ 2-2-1 Itsukaichikou, Saeki-ku, Hiroshima 731-5161 Japan \\ ${ }^{* 2}$ Department of Mechanical Science and Engineering, Hiroshima University \\ 1-4-1 Kagamiyama, Higashi-Hiroshima-shi, Hiroshima 739-8527, Japan
}

Received 31 March 2015

\begin{abstract}
Hydraulic excavators and cranes are major heavy equipment with numerous one-sided welded joints. Although fillet weld joints are easily implemented and economical, the unwelded portion frequently initiates crack propagation. Therefore, the welded portion is reduced by side welding and by adding a groove. However, attachments with box like structures are difficult to weld at both sides, and grooving cannot completely remove the welded portion because high-quality full penetration welds are difficult to achieve. Despite the need for an accurate evaluation method of crack propagation, the fatigue fracture mechanism and the fatigue damage in practical fillet joints with one-sided welding remains poorly understood. In this study, the fatigue properties and the fracture mechanism of the load carrying type fillet joints with one-sided welding were investigated experimentally to evaluate its fatigue damage with high accuracy based on the experimental results. As the results, fatigue cracks in the test piece initiated from the tip of the unwelded portion and propagated into the welding materials. The three-dimensional observations revealed that fatigue cracks initiate at an early stage of the fatigue development. So, we infer that the fatigue lifetime is chiefly governed by the crack propagation lifetime. Furthermore, from the three-dimensional observation results, cracks were initiated at multiple sites in the test piece. As the number of cycles increased, these cracks propagated and combined.
\end{abstract}

Key words : One-sided welded joint, Fatigue, Crack propagation, 3-Dimensional observation

\section{1. 緒言}

油圧ショベルには多くの溶接継手があり，特に作業機部分（アタッチメント）にはすみ肉溶接継手が多く用い られている．才み肉溶接継手は施工性や経済性に優れる継手であるが，溶接未溶着部が残り，疲労き裂進展の起 点となる場合があるため，両側すみ肉溶接や開先加工による対策が行われてきた。しかしながら，箱型構造を有 するアタッチメントの場合は，全部位に両側すみ肉溶接を施工することは難しい．また開先加工を施工した場合 でも片側すみ肉溶接では高品質な完全溶け込みを確保することは難しいため, 未溶着部を完全に無くすことはで きない. そのため, 未溶着部の強度を精度よく評価する方法は強度およびコストを両立させた最適設計をする際に

\footnotetext{
No.15-00181 [DOI: 10.1299/transjsme.15-00181], J-STAGE Advance Publication date : 10 December, 2015

*1 正員，コベルコ建機（株）（干731-5161 広島県広島市佐伯区五日市港 2-2-1）

*2 正員, 広島大学 工学部（干739-8527 広島県東広島市鏡山 1-4-1）

E-mail of corresponding author: abe.takamasa@kobelco.com
} 
大変重要である.一般的に未溶着部の先端は鋭い切欠き形状となるため, 破壊力学を用いた応力拡大係数とパリス 則により二次元き裂の寿命予測評価を行う.工学上有用な指針(一般社団法人, 日本鋼構造協会, 2012), (一般社 団法人, 日本溶接協会, 2011)も提案されており,多くの設計現場で運用されている. しかし, 実際の構造物は溶接 線が非常に長く三次元的にき裂が進展する可能性がある場合においては, 整合性が高い評価となっているか不明 確である.また, 工学上は未溶着部の長さを初期き裂として扱っているが, 実際には未溶着部の先端からき裂が発 生する挙動があると考えられるため, 全寿命に対してき裂発生寿命が長い場合は, き裂発生寿命も評価に含めるこ とで更なる評価精度の向上が見込める.さらに, 実際の構造物においては長い溶接線の中にスラグや空孔などの溶 接欠陥も存在する場合があるが, 実機における欠陷数や位置が疲労き裂の進展挙動, さらには疲労寿命にどのよう な影響を及ぼしているかも不明確である。

これまでも, 溶接未溶着部の疲労強度に関する多くの報告があるものの, 報告(Bell et al., 1989), (Carpinteri et al., 2005), (Chung et al., 2008), (Kainuma and Mori, 2006), (Kanvinde et al., 2009), (Miki et al., 1993), (森, 貝沼, 1994), (中込他, 1994), (Otegui et al., 1991), (山田他, 2001)の多くは十字型および T 字型の両側すみ肉溶接継手 を対象としており, 片側すみ肉溶接継手に対する報告(森, 2003)は少ない. 荷重伝達型の報告はさらに僅少である. 実機に関する報告もあり，多くは S-N 曲線に基づく寿命予測や応力拡大係数を用いた寿命推定評価をしているも のの, き裂進展挙動にまで言及した評価は行われていないようである.

構造物内部のき裂進展挙動を調査し, 現象に基づいた寿命予測を行うことができれば, 評価精度の向上が図れる と考えられる.そこで, 本研究では実機を再現した試験体を製作し, 疲労試験を実施した. さらに, 表面からの通 常観察が困難である内部き裂進展挙動を三次元的に観察することで片側すみ肉溶接部の疲労特性について検討を 行った.

\section{2. 供試材料および実験方法}

\section{$2 \cdot 1$ 供試材料}

本研究では構造上応力状態が厳しくなる図 1 に示寸油圧ショベルのアタッチメントのブーム部を対象とした. 一般にアタッチメントはブーム, アーム, バケットがリンクや油圧シリンダで連結されており, 油圧シリンダの 伸縮により作動するしくみである. 本研究で対象とした部位の断面は図 2 に示寸箱型構造となっており, ブラケ ットには油圧シリンダ推力が荷重として作用寸る. 本研究では実機と同一の板厚寸法, 溶接材, 溶接施工条件, 負荷形式を再現した試験体を製作した．以下に製作手順を示す．母材には油圧ショベルのアタッチメント部にも 用いられる構造用鋼材 JIS SS400 相当材を用いた．同材をアーク溶接による片側すみ肉溶接にて図 3 に示す L 型 形状に接合した。 その際, アタッチメントのブラケット部も L 型部材に接合し試験体のつかみ部（同図中(a)）と した. 加えて溶接歪による変形を抑えるための歪防止板（同図中(b)）を両側すみ肉溶接にて接合した．用いたア 一ク溶接条件を表 1 に示す. なお溶接後の応力除去焼鈍は実施していない. 次に, 接合した L 字部材を, ワイヤ 一カットにより図 3 中破線で示す通り, 溶接の開始部および終端部を除く部分を溶接線方向 $50 \mathrm{~mm}$ 切断し, 図 4 に示寸試験体を製作した，用いた溶接材は実機同様 JIS Z3313 相当品であり，その化学組成，および機械的性質 は表 2, および表 3 の通りである（両表ともカタログ值）.

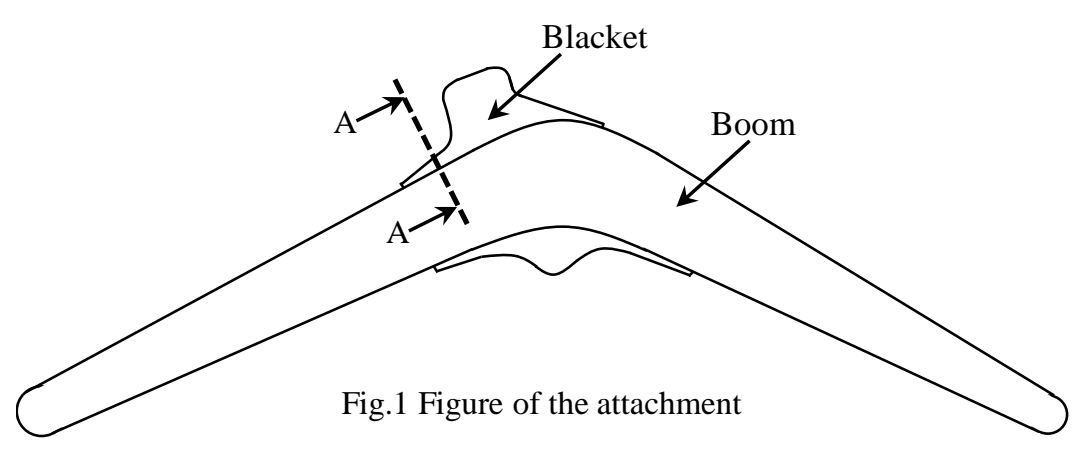

Fig.1 Figure of the attachment

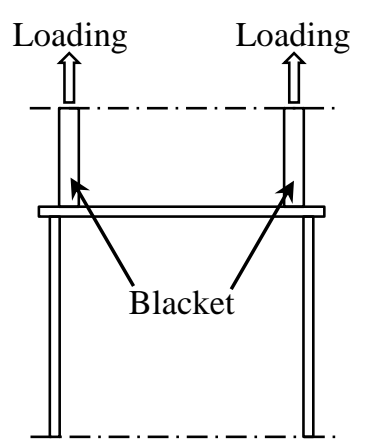

Fig.2 Section of the attachment A-A 


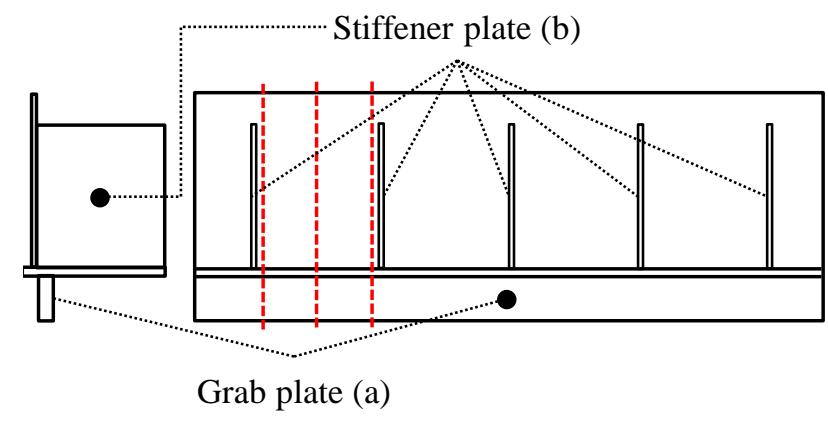

Fig.3 Manufacturing specimens

Table1 Welding Condition

\begin{tabular}{|c|c|c|}
\hline $\begin{array}{c}\text { Welding Current } \\
(\mathrm{A})\end{array}$ & $\begin{array}{c}\text { Arc Voltage } \\
(\mathrm{V})\end{array}$ & $\begin{array}{c}\text { Welding Speed } \\
(\mathrm{cm} / \mathrm{min})\end{array}$ \\
\hline 270 & 31 & 50 \\
\hline
\end{tabular}

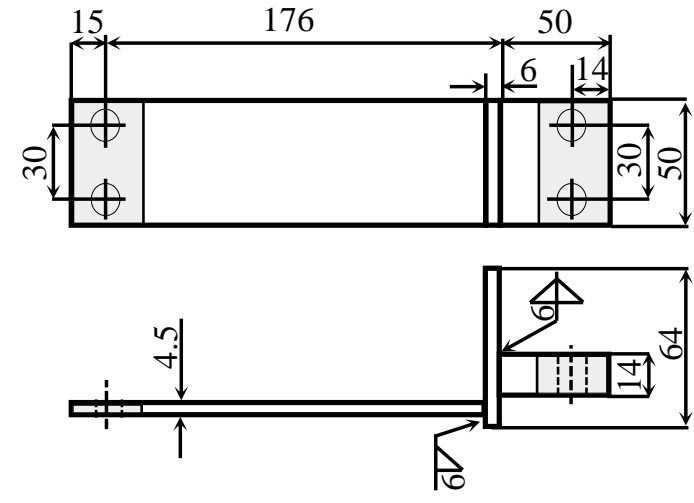

Fig.4 Shapes and dimensions of specimens

Table2 Chemical composition of welding material [mass\%]

\begin{tabular}{|c|c|c|c|c|c|}
\hline Material & $\mathrm{C}$ & $\mathrm{Si}$ & $\mathrm{Mn}$ & $\mathrm{P}$ & $\mathrm{S}$ \\
\hline $\begin{array}{l}\text { Welding } \\
\text { material }\end{array}$ & 0.06 & 0.5 & 1.4 & 0.013 & 0.009 \\
\hline
\end{tabular}

Table3 Mechanical properties of welding material

\begin{tabular}{|c|c|c|c|}
\hline $\begin{array}{c}\text { Yield } \\
\text { strength } \\
\sigma_{\mathrm{y}}(\mathrm{MPa})\end{array}$ & $\begin{array}{c}\text { Tensile } \\
\text { strength } \\
\sigma_{\mathrm{B}}(\mathrm{MPa})\end{array}$ & $\begin{array}{c}\text { Elongation } \\
\delta(\%)\end{array}$ & $\begin{array}{c}\text { Absorbed } \\
\text { energy }(\mathrm{J})\end{array}$ \\
\hline 530 & 590 & 29 & 98 \\
\hline
\end{tabular}

\section{$2 \cdot 2$ 実験方法}

疲労試験には島津製作所製油圧式サーボパルサーを用い，図 4 中灰色部を治具に固定し，図中左右方向に繰返 し負荷を与えることにより，実機同様の負荷様式を再現した。なお，試験体を治具に固定する際，試験体にひず みゲージを貼付し，無負荷状態での初期ひずみが $50 \mu \varepsilon$ 以下となるようにボルト締付け力を調整した。（ひずみゲ ージ貼付位置は図 5 を参照 $)$. 疲労試験は室温大気中, 周波数 $f=20 \mathrm{~Hz}$, 荷重比 $R_{\mathrm{F}}\left(=F_{\min } / F_{\max }\right)=0.05$ の一定試験力 振幅下で行った。 なお，溶接接合部が完全に分離した時点を破断と定義し，試験打ち切り回数は $N=10^{7}$ cycles と した.

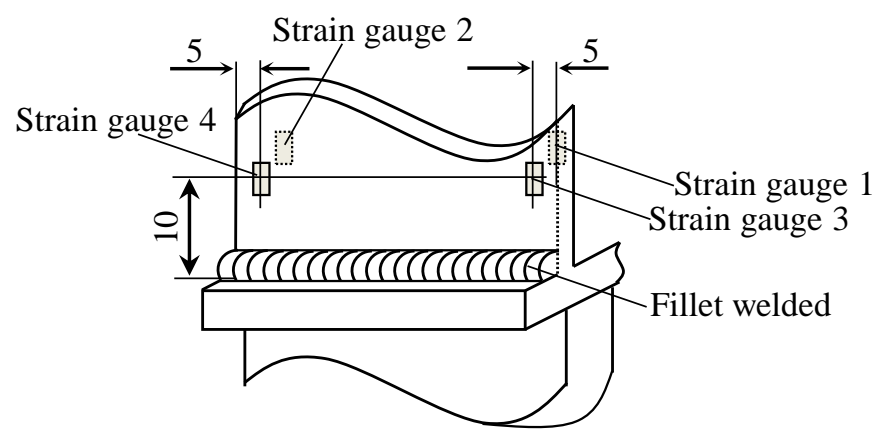

Fig.5 Position of the strain gauge near fillet weld

\section{3. 実験結果および考察}

\section{$3 \cdot 1$ 組織観察}

図 6 に片側すみ肉溶接部断面の組織観察結果を示す.同図より,本試験体の寸み肉溶接部近傍には，溶接金属部 分, その周辺の熱影響部（HAZ 部）, および母材部に分類される 3 つの組織領域が存在していることが分かる. 各 領域における組織観察結果より，溶接金属部の組織は溶融凝固したデンドライト組織であり，母材部にはフェラ イト組織が確認された. また母材部から溶接金属部に近づくにしたがい, 結晶粒が粗大化していることが確認でき た. 


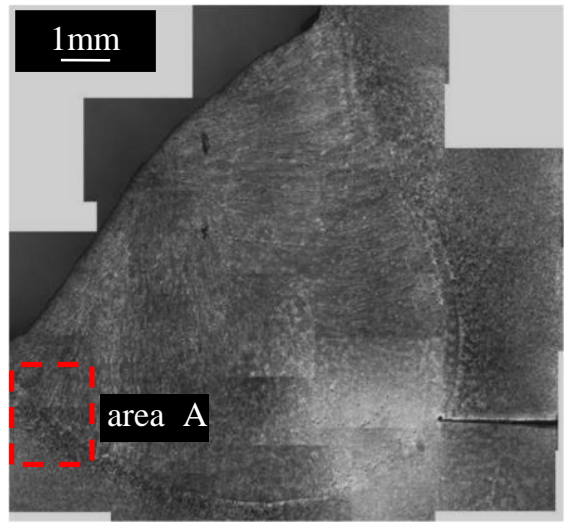

(a) Low magnification image

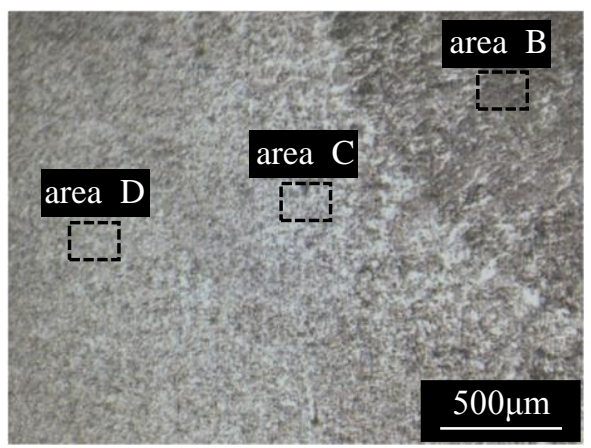

(b) High magnification image in area A

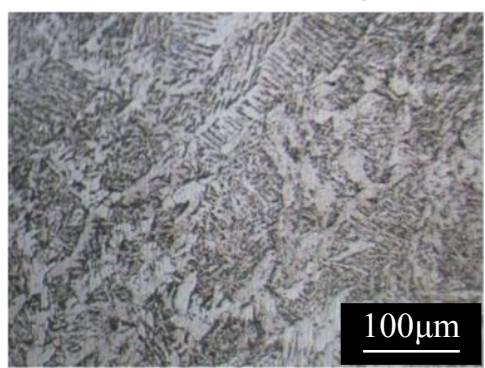

(c) Microstructure in welded metal $(\operatorname{area} \mathrm{B})$

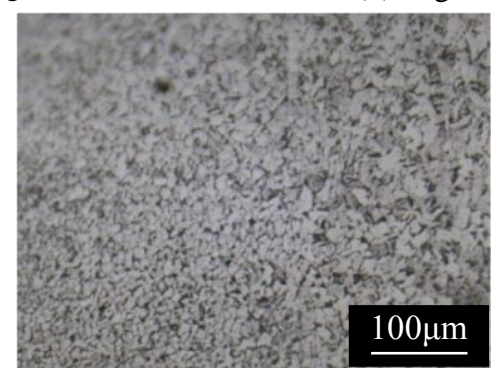

(d) Microstructure in HAZ (area C)

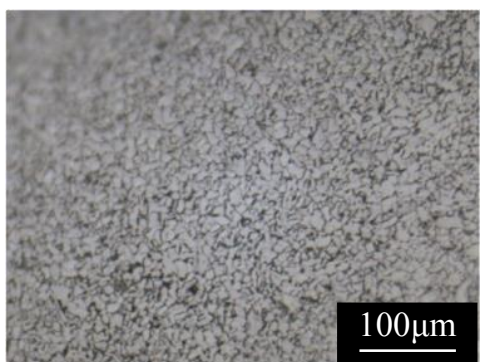

(e) Microstructure in base metal (area D)

Fig.6 Microstructure near the fillet weld

\section{$3 \cdot 2$ 疲労試験結果}

図 7 に疲労試験結果を示す。同図縦軸は試験体に作用する試験力振幅，横軸は破断に至るまでの繰返し数であ る. 同図より, 試験力振幅 $F_{\mathrm{a}}=7 \mathrm{kN}$ において最大 4 倍程度の疲労寿命差が認められるものの，概ねばらつきの少 ない疲労寿命曲線が得られることが分かる. なお, $F_{\mathrm{a}}=5 \mathrm{kN}$ において, 試験打ち切り回数 $N=10^{7}$ cycles に達した.

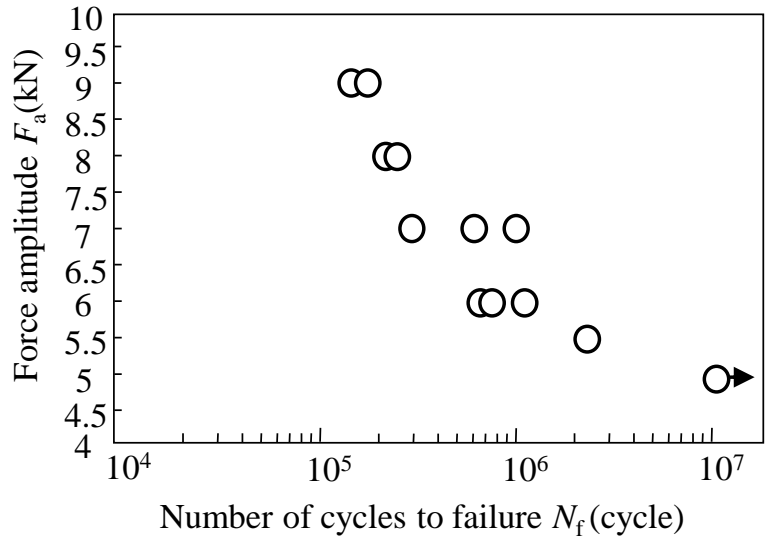

Fig.7 $F_{\mathrm{a}}-N$ curve

Number of cycles to failure $N_{\mathrm{f}}$ (cycle)

The vertical and horizontal axes indicate the amplitude of the force applied to the test piece, and the number of cycles to failure, respectively. Apart from $F_{\mathrm{a}}=7 \mathrm{kN}$, which exhibits widely spread lifetimes, the dispersion of the $\mathrm{S}-\mathrm{N}$ curve is small. At $F_{\mathrm{a}}=5 \mathrm{kN}$, the lifetime extends to $10^{7}$ cylces.

\section{3-3 巨視的破壊形態と破面観察結果}

破断した全ての試験体について，巨視的破壊形態の観察を行った。観察結果の代表例として，試験力振幅 $F_{\mathrm{a}}=6$ $\mathrm{kN}$ にて破断した試験体の溶接部近傍を側面から観察した巨視的観察結果を図 8 に示す. 同図より, 本試験体は未 溶着部先端から発生した疲労き裂が，荷重軸垂直方向に対しある程度の角度を有し溶接金属部内を進展し，その 後最終破壊を呈することが分かる。さらに，試験力振幅 $F_{\mathrm{a}}=6 \mathrm{kN}$ にて破断した試験体破面を荷重軸方向から巨視 的に観察した結果を図 9(a)に，走査型電子顕微鏡（日立製作所 S-3000N）を用いて詳細な破面観察を行った結果 を図 9(b), (c)に示す。困 9(a)に示すように，本試験体にはブローホールなどの内部溶接欠陥（図中破線矢印部分） が存在したが，位置や個数と，破断繰返し数を比較すると両者に明瞭な相関は認められなかった。また詳細は後 
述するが，未溶着部近傍に存在する溶接欠陥が疲労き裂発生，および進展挙動へ及ぼす影響は少ないことから， 溶接金属部の内部溶接欠陥が本試験体の疲労特性に及ぼす影響はほとんどないものと考えられる.

同様に図 9(b)より未溶着部先端から広範囲に典型的な疲労破面が, 図 9(c)より未溶着部先端から $5 \mathrm{~mm}$ 程度の領 域には延性破面が認められた，以上の巨視的，および微視的観察結果から，本試験体は未溶着部から発生した疲 労き裂が，繰返し負荷に伴い $5 \mathrm{~mm}$ 程度溶接金属部内を進展し，その後静的破壊を伴う最終破断に至る疲労破壊 形態を呈することが明らかとなった。

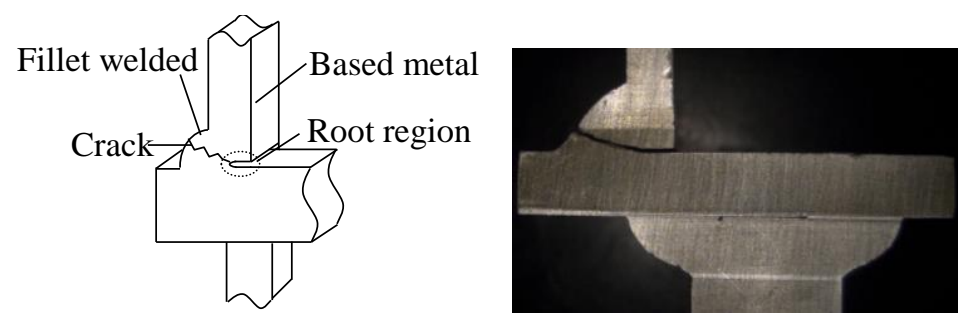

Fig.8 Representative sample

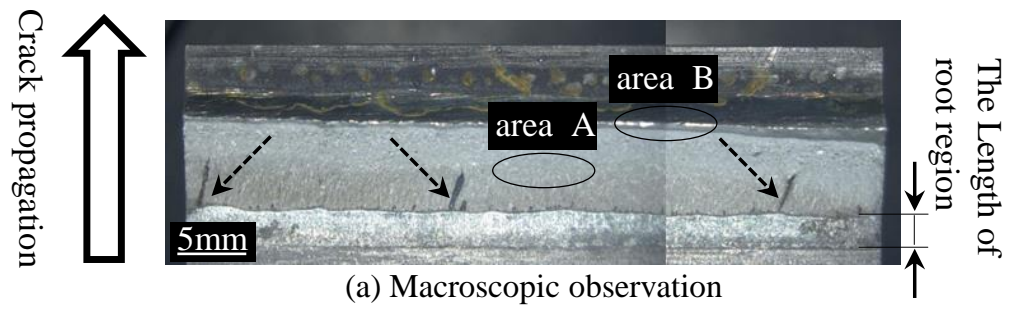

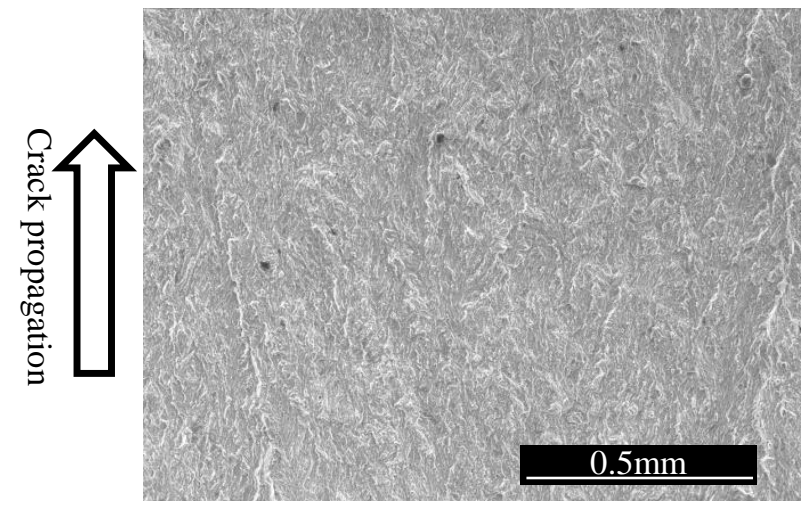

(b) Magnified image in area A

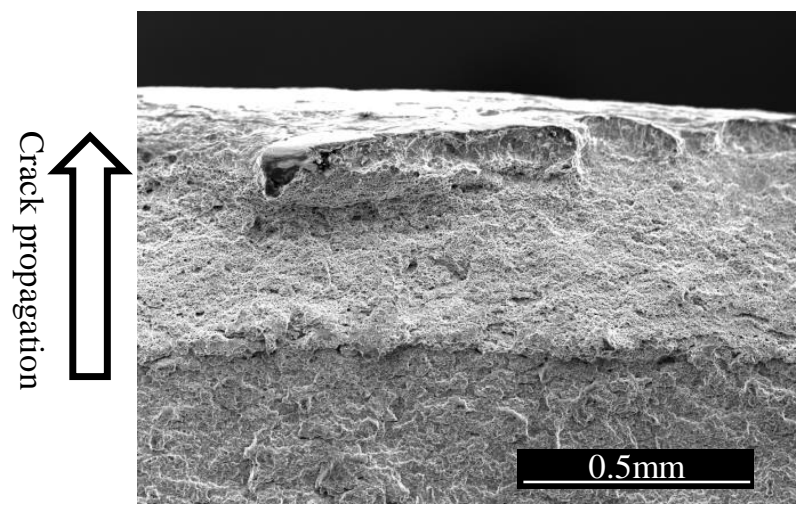

(c) Magnified image in area B

Fig. 9 Macro observation $\left(F_{\mathrm{a}}=6 \mathrm{kN}, N_{\mathrm{f}}=6.4 \times 10^{5}\right.$ cycles $)$

Many welding defects of various sizes appear in the test pieces. However, the sizes and numbers of the welding defects are unrelated to the number of cycles to failure. The details of fracture were examined under a scanning electron microscope (SEM) (Hitachi, Ltd S-3000N). Typical fatigue fractures spread over a wide area (panel (b)), and the ductile fracture extends to $5 \mathrm{~mm}$ from the tip of the welding portion (panel (d)). According to the macroscopic and microscopic observations, cracks are initiated at the tip of the welding defect, and propagate $5 \mathrm{~mm}$ into the welding material leading to final fracture.

\section{$3 \cdot 4$ き裂発生挙動観察}

本節では，未溶着部先端から発生する疲労き裂をより詳細に観察することにより，疲労き裂発生挙動，および き裂発生に及ぼす溶接欠陥の影響について考察を加える.

図 10, および図 11 に未溶着部近傍の断面観察結果を示寸. 同図は, 試験力振幅 $F_{\mathrm{a}}=9 \mathrm{kN}$ にて疲労試験を行い, 試験途中に停止した試験体を荷重軸方向に切断し得られた未溶着部近傍の断面観察結果であり, 両図は同一試験 体の異なる断面位置の観察画像を示している. なお, 同図の試験停止繰返し数 $N_{\text {stop }}$ は $8 \times 10^{3}$ cycles であり, 実際の 疲労試験で得られた同試験カレベルにおける推定破断寿命 $N_{\mathrm{f}, \mathrm{est}}$ は $1.6 \times 10^{5} \mathrm{cycles}$ である $\left(N_{\mathrm{stop}} / N_{\mathrm{f}, \mathrm{est}}=5 \%\right)$.

図 10 より, 前節の巨視的観察結果同様, 未溶着部先端において発生した疲労き裂が溶接金属部内に進展してい ることが分かる.なお,前述した通り, 疲労き裂は巨視的には荷重軸垂直方向に対しある程度の角度を有し進展して いたが, 発生直後の微小き裂はほぼ荷重軸垂直方向に進展していることも分かる. また図 11 より, 未溶着部近傍 に比較的大きな溶接欠陥がある場合においても疲労き裂は未溶着部先端から発生していることから, 未溶着近傍 の溶接欠陥がき裂発生箇所に及ぼす影響は大きくないと考えることができる. 

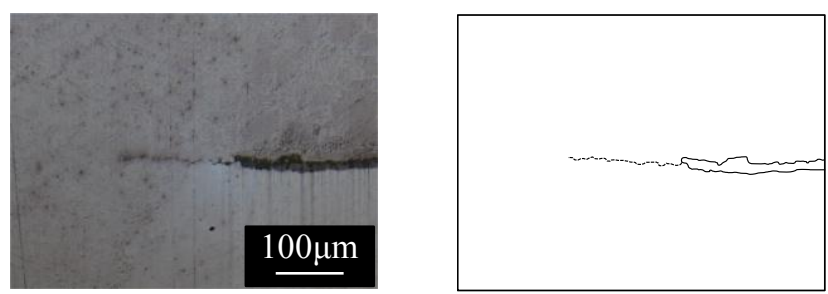

Fig.10 Crack propagation from the root tip of the welding portion

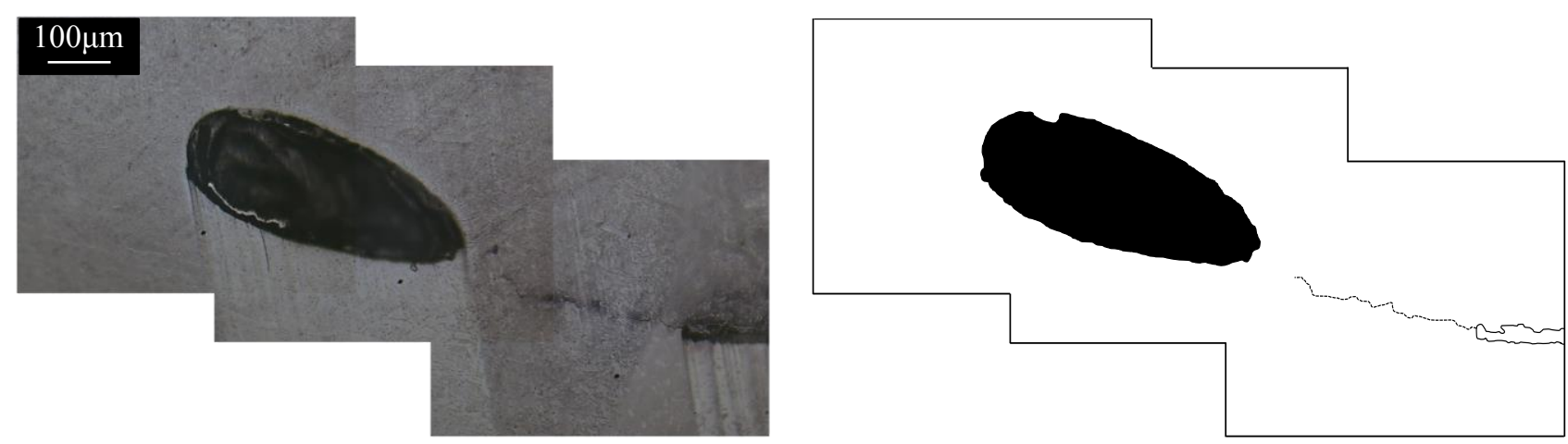

Fig.11 Crack propagation from the root tip of the welding portion near welding defect

\section{$3 \cdot 5$ き裂進展挙動}

本節では，溶接金属部内を進展する疲労き裂の進展挙動について考察を行う。ここで本試験体のような片側す み肉溶接継手の場合，通常の観察手法により未溶着部から発生したき裂の進展挙動を把握することは非常に困難 である，そこで本研究では，所定の繰返し数で停止した試験片を切断することにより，未溶着部近傍の疲労き裂 進展挙動を三次元的に観察した. 以下に観察手法の詳細を示す.

まず推定破断寿命 $N_{\mathrm{f}, \mathrm{est}}$ に対し，x\%の繰返し数 $N_{\text {stop }}$ で試験を中断し，試験片片側側面を研磨した後エッチング 処理を行い，光学顕微鏡により溶接部近傍の側面写真を得る. その後，溶接線方向に $300 \mu \mathrm{m} \sim 500 \mu \mathrm{m}$ 程度研磨 し，その側面に対し同様に溶接部近傍の側面写真を得る。これを溶接線方向に対し複数回繰返し，得られた側面 写真から，三次元化グラフ作成ソフトを用いてき裂を三次元的に再現した. なお，本研究では低試験力レベルと して $F_{\mathrm{a}}=6 \mathrm{kN}$ ，高試験力レベルとして $F_{\mathrm{a}}=9 \mathrm{kN}$ をそれぞれ選定し，各試験力レベルにおけるき裂の三次元化を行 つた. 各試験力レベルにおける推定破断寿命 $N_{\mathrm{f}, \mathrm{est}}$ は，実際の疲労試験で得られた各試験力レベルにおける最長寿 命（ $F_{\mathrm{a}}=6 \mathrm{kN}: N_{\mathrm{f}, \mathrm{est}}=1.1 \times 10^{6}$ cycles, $F_{\mathrm{a}}=9 \mathrm{kN}: N_{\mathrm{f}, \mathrm{est}}=1.6 \times 10^{5}$ cycles $)$ を採用した。

上述の観察手法により得られた低試験力レベル $\left(F_{\mathrm{a}}=6 \mathrm{kN}\right)$ ，および高試験力レベル $\left(F_{\mathrm{a}}=9 \mathrm{kN}\right)$ におけるき裂の 三次元化画像を図 12(a), (b), (c), 図 13(a), (b), (c)にそれぞれ示す. 両図とも推定破断寿命 $N_{\mathrm{f}, \text { est }}$ に対し $5 \%$, 25\%, および 50\%時点でのき裂の三次元化画像であり, 試験体板幅方向（=溶接線方向）の縮尺に対し, き裂進展方向 の縮尺がおよそ 30 倍に表示されている．X 軸は試験体幅方向，Y 軸は試験体奥行き方向，Z軸が試験体上下方向 をそれぞれ示す。

まず，推定破断寿命 $N_{\mathrm{f}, \text { est }}$ に対し 5\%時点でのき裂様相に注目すると（両図(a)），試験力レベルによらず試験体幅 $50 \mathrm{~mm}$ 全ての範囲で長さ $0.01 \mathrm{~mm} \sim 0.3 \mathrm{~mm}$ のき裂が認められ，推定破断寿命 $N_{\mathrm{f}, \mathrm{est}}$ に対し非常に早い段階でき裂が 発生していることが分かる。このことは，本試験体の疲労寿命はき裂進展寿命が支配的であること，すなわち本 試験体の疲労損傷評価には疲労き裂進展を考慮した破壊力学的アプローチが有効であることを示唆するものであ る.

さらに疲労損傷を与えた $N_{\text {stop }} / N_{\mathrm{f}, \mathrm{est}}=25 \%$ 時点では（両図(b)）, 疲労試験極初期に発生したき裂が溶接金属部内を 進展している様子が分かる。ここでき裂前縁に注目すると，本試験体に認められるき裂前縁は，直線形状，もし くは緩やかな半楕円形状を有しておらず, 一部がき裂進展方向に突出し, 凸型形状が複数個重なった複雑な形状 であることが分かる．さらに疲労損傷を与えた $N_{\mathrm{stop}} / N_{\mathrm{f}, \mathrm{est}}=50 \%$ 時点でのき裂形状においても（両図(c)）この傾向 は変わらず，き裂前縁形状は複雑な形状を維持したままであることが分かる。これらの観察結果は，未溶着部先 端において異なる複数の箇所から疲労き裂が発生し, それらが進展・合体を繰返し試験体の最終破壊を導くこと を示唆するものである.

ここで, 図 12, 図 13 に示した疲労き裂の三次元化画像は, 試験途中の試験体を切断し観察することにより得ら れるため, 同一試験体中を進展するき裂を連続的に観察することは不可能である. そこで次に, ビーチマーク法 
を用い同一試験体の疲労き裂前縁を確認することにより，き裂発生起点数についてさらに詳細な検討を行った. 図 14 に疲労破面に形成されたビーチマーク観察結果を示す. 同図は, 試験力振幅 $F_{\mathrm{a}}=6 \mathrm{kN}$ （荷重比 $R_{\mathrm{F}}=0.05 ） に$ て疲労試験を行い, ある繰返し数毎にビーチマークを形成する以下の試験 3 条件, (1)試験力振幅 $F_{\mathrm{a}}=2.1 \mathrm{kN}, R_{\mathrm{F}}=0.66$, (2)試験力振幅 $F_{\mathrm{a}}=1.7 \mathrm{kN}, R_{\mathrm{F}}=0.72$, (3)試験力振幅 $F_{\mathrm{a}}=1.4 \mathrm{kN}, R_{\mathrm{F}}=0.76$, にて試験を行うことにより，その際のき裂 前縁を明瞭化した破面である. 同図中には破面より認められるき裂前縁の模式図, およびその際の繰返し数（ビ 一チマーク形成図の繰返し数を除く）を付記している．同図より，ビーチマーク法を用いたき裂前縁の連続的観 察からも, 本試験体には複数のき裂発生起点が認められること, さらに繰返し数の増加に伴いそれらが合体挙動 を伴い進展している様子が明瞭に確認できる.

以上，き裂の三次元的，およびビーチマーク法による観察結果から，本試験体の疲労損傷評価には，複数起点 から発生する疲労き裂の合体挙動を考慮した破壊力学的アプローチが有効であるといえる. なお，試験力振幅 $F_{\mathrm{a}}=5 \mathrm{kN}$ において試験打切り回数 $N=10^{7}$ cycles に到達した試験体についてもき裂の三次元的観察を行った. 結果を 図 15 に示寸. 同図より, 試験打切りに至った試験体においても疲労き裂が発生, 進展していることを確認した.

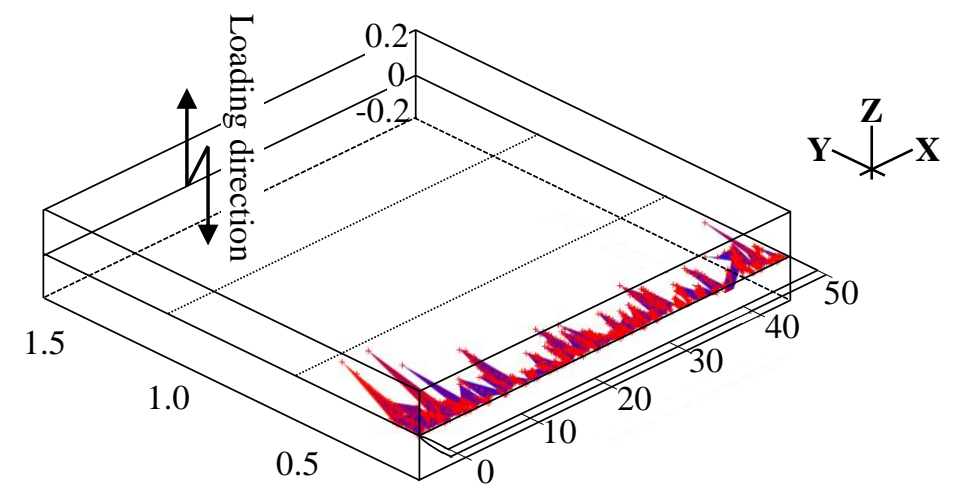

(a) $N_{\text {stop }} / N_{\text {f,est }}=5 \%$

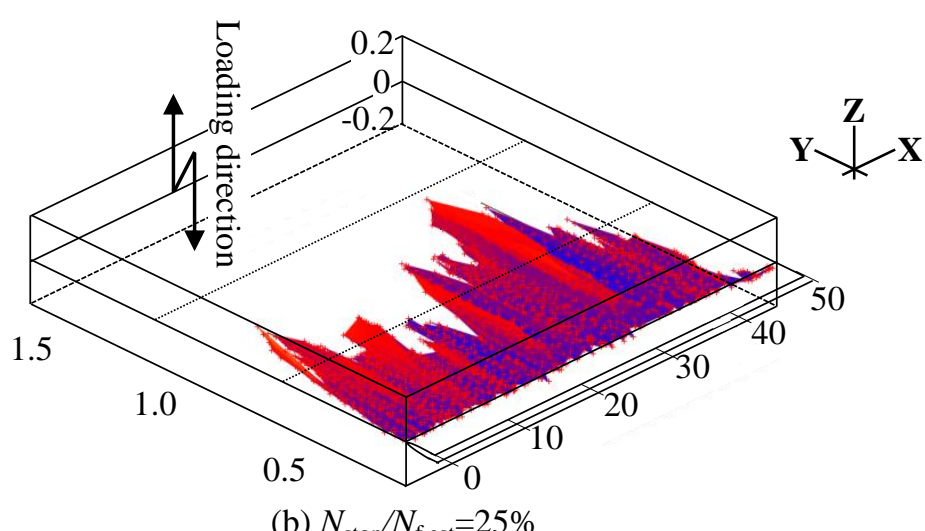

(b) $N_{\text {stop }} / N_{\text {f,est }}=25 \%$

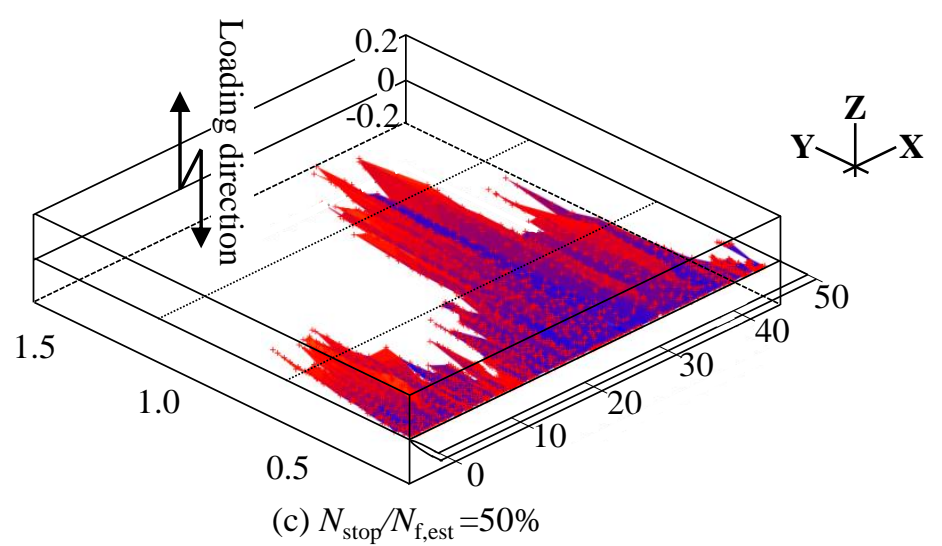

Fig. 12 3-dimentional observation of fatigue crack propagation from the tip of the welding portion $\left(F_{\mathrm{a}}=6 \mathrm{kN}\right)$ Cracks initiate at a very early stage of the estimated rupture life $N_{\mathrm{f}, \mathrm{est}}$. 


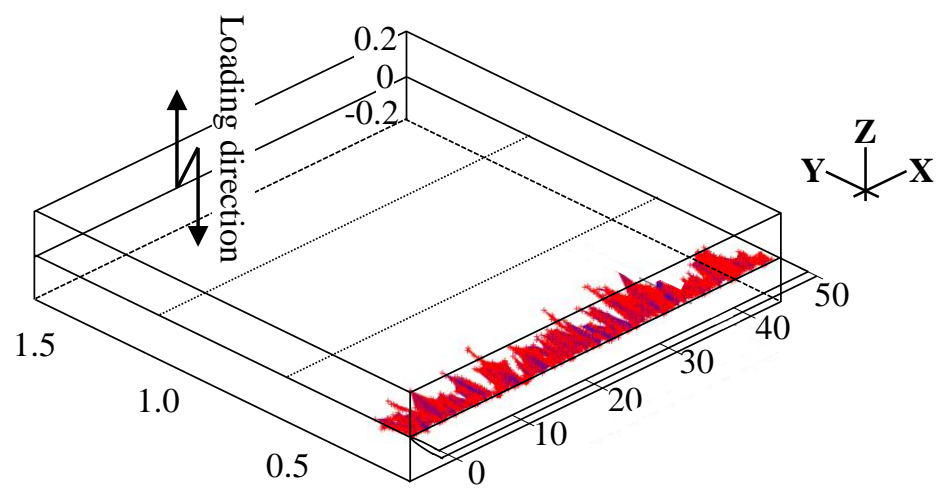

(a) $N_{\text {stop }} / N_{\text {f,est }}=5 \%$

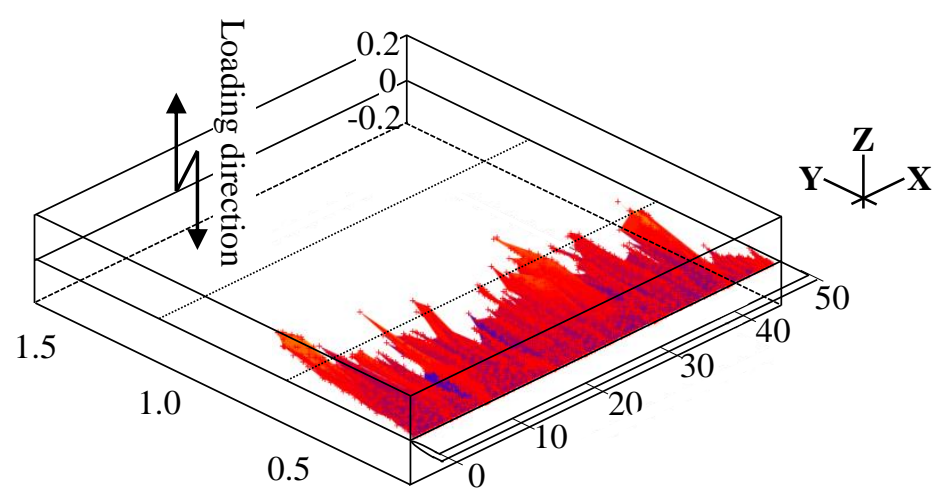

(b) $N_{\text {stop }} / N_{\text {f,est }}=25 \%$

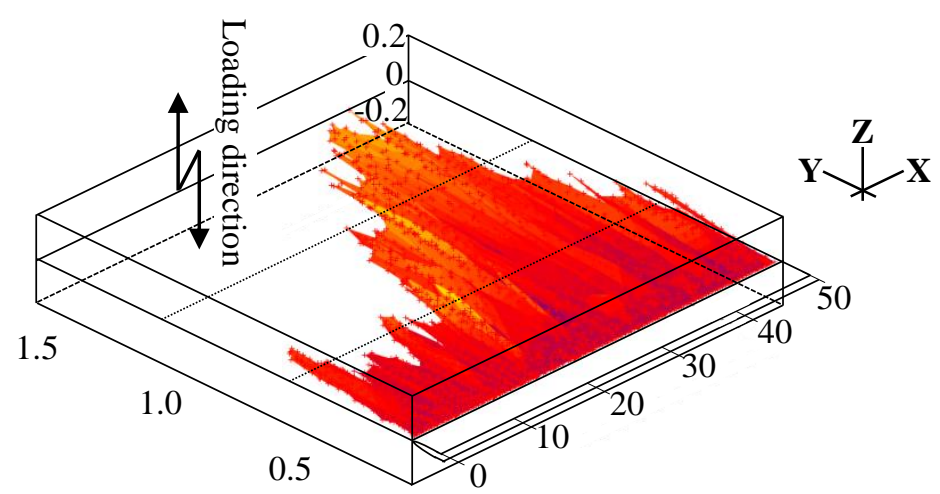

(c) $N_{\text {stop }} / N_{\text {f,est }}=50 \%$

Fig.13 3-dimentional observation of fatigue crack propagation from the tip of the welding portion $\left(F_{\mathrm{a}}=9 \mathrm{kN}\right)$ The overall patterns do not evolve, and the leading edge of the crack is complex shape. Multiple cracks initiated at multiple origins coalesce as they propagate.
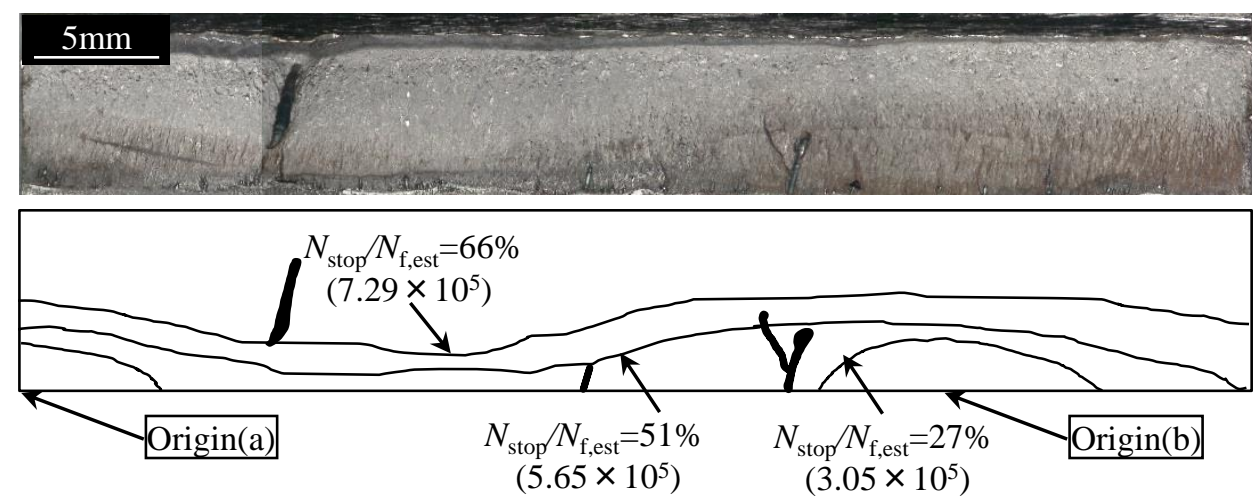

Fig.14 Beach mark on fracture surface of $F_{\mathrm{a}}=6 \mathrm{kN}$ 


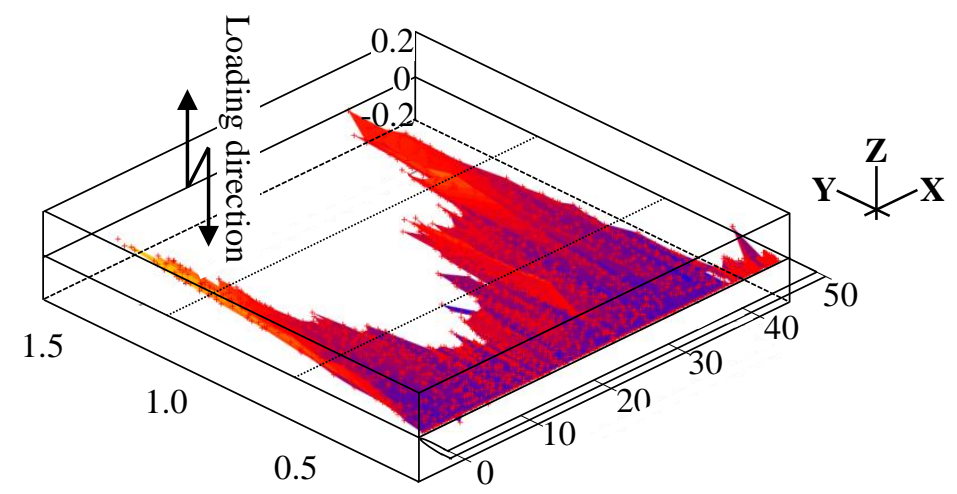

Fig.15 3-dimentional observation of fatigue crack propagation from the tip of the welding portion $\left(F_{\mathrm{a}}=5 \mathrm{kN}, N=10^{7} \mathrm{cycles}\right)$

\section{$3 \cdot 6$ き裂発生起点と未溶着部形状の関係}

前節の観察結果より，本試験体は複数のき裂発生起点を有することが明らかとなった．本節では，いかなる箇 所がき裂発生起点部となりうるかを検討するため, 未溶着部先端形状に注目し考察を加える. 図 16 に本試験体に おける代表的な未溶着部先端形状を示す. 先端形状は(a)と(b)に大別される. 先端形状の鋭さを数值化するために, き裂の三次元化観察により得られた側面画像から, 未溶着部先端からき裂進展方向と反対方向に $10 \mu \mathrm{m} の$ 位置に おける未溶着部隙間 $(S)$ を定義し未溶着部先端形状の定量的評価指標とした. 結果を図 17 に示す，多くの未溶着 部隙間 $(S)$ は 0.02〜0.03mm 程度である（図 17(b), (d)）ことがわかるが，一部図 17(a), (c)に示すような極端に狭い 未溶着部先端を有する箇所が 1 つの試験体中に複数個所認められた. 図 17 において, $F_{\mathrm{a}}=6 \mathrm{kN}$ の結果は図 $12(\mathrm{c})$ に, $F_{\mathrm{a}}=9 \mathrm{kN}$ の結果は図 13(c)の三次元化観察結果に対応する.未溶着部先端からのき裂長さが長い箇所において 鋭い先端形状を有していることが確認できる.よって，このような鋭い先端を有する未溶着部が疲労き裂発生の 起点となった可能性が高いと考えられる.

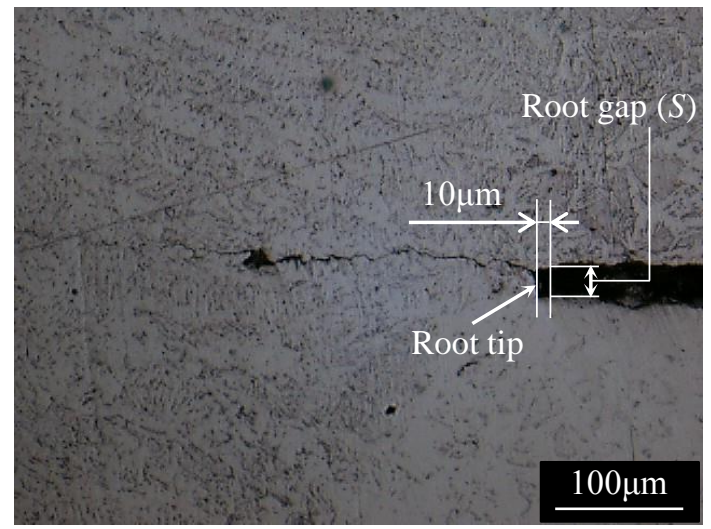

(a) Root tip

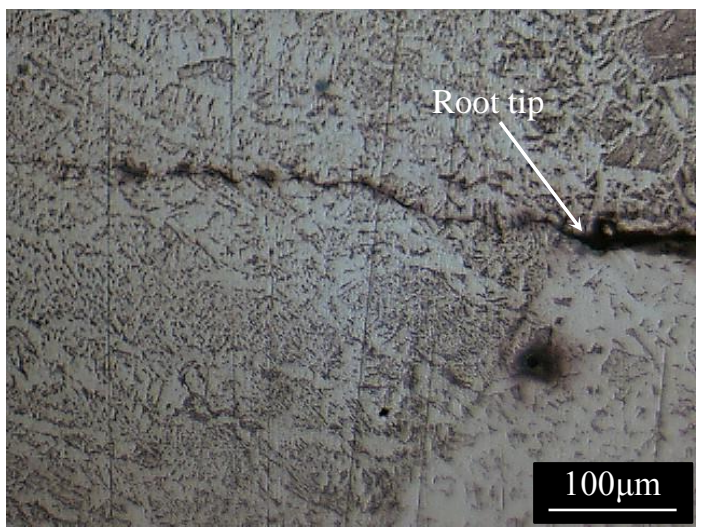

(b) Narrow root tip

Fig.16 Typical observations of the unwelded portion
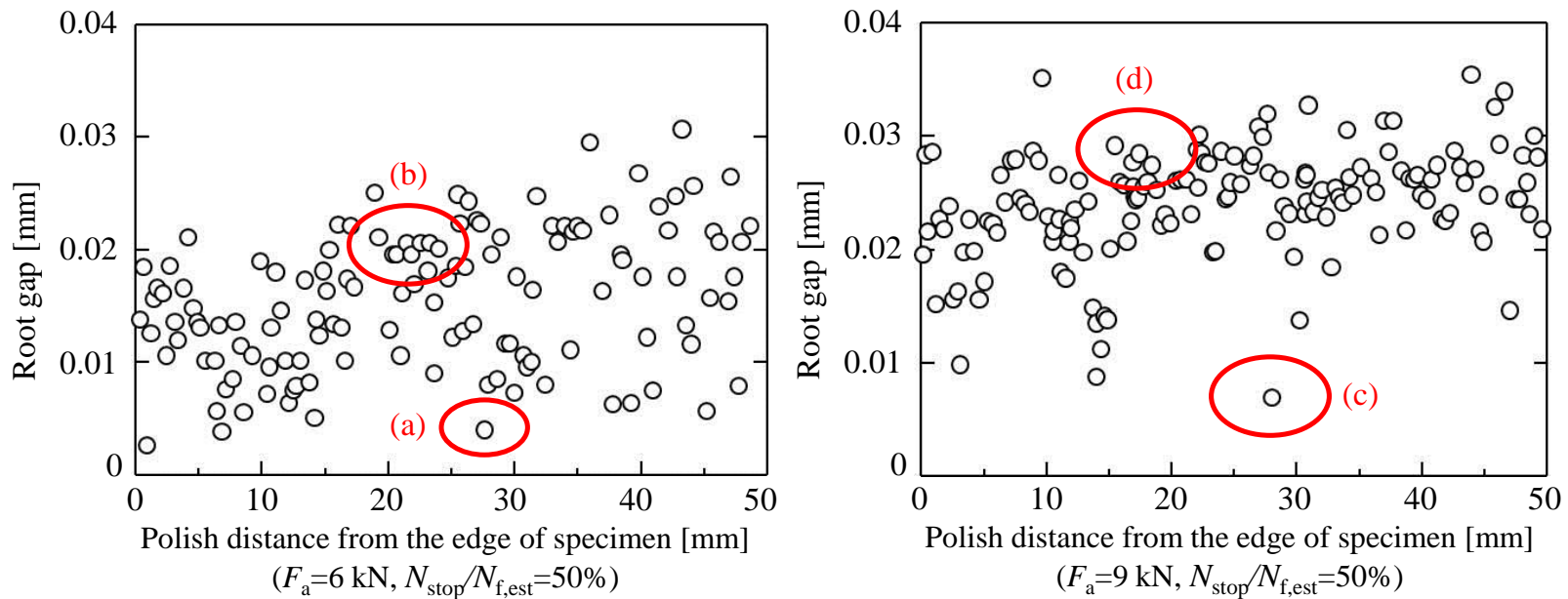

$\left(F_{\mathrm{a}}=6 \mathrm{kN}, N_{\text {stop }} / N_{\text {f,est }}=50 \%\right)$ $\left(F_{\mathrm{a}}=9 \mathrm{kN}, N_{\text {stop }} / N_{\mathrm{f} \text { est }}=50 \%\right)$

Fig.17 Root gaps in the unwelded portion 


\section{$3 \cdot 7$ 欠陥とき裂進展挙動}

$3 ・ 4$ 節では，疲労き裂発生挙動に及ぼす溶接金属部中に存在する溶接欠陥の影響について述べた．本節では， 溶接欠陥が及ぼす疲労き裂進展への影響について考察を加える. 図 18 は, 試験力振幅 $F_{\mathrm{a}}=9 \mathrm{kN}$ において疲労試験 を実施し, $N / N_{\mathrm{f}}=25 \%$ 時点で中断した試験体に対し, 前述の三次元化手法と同様の方法により得た未溶着部近傍の 観察結果である. なお，図 18 の section A〜section F は溶接線方向に順に並んでおり，各画像の溶接線方向間隔は およそ $20 \mu \mathrm{m} \sim 90 \mu \mathrm{m}$ である.

同図より， section A では溶接欠陥が未溶着部先端に存在するが，疲労き裂は溶接欠皕の影響を受けず，ほぼ荷 重軸垂直方向に進展していることが分かる.これに対し, section B, C, D では, 未溶着部先端から発生した疲労き 裂が，溶接欠陥に吸い込まれるように進展方向を変えており，溶接欠陥の存在がき裂進展方向に影響を及ぼして いることが認められる．しかしながら，その後の進展により，溶接欠陥の影響を受けていないき裂面（section A） と同じ位置に進展方向を変えていることも分かる.ささら， section E, Fにおいて溶接欠陥が消失するに伴い，こ のようなき裂進展方向の変化も認められなくなる. なお, 久陥の屈曲に関寸る藤原ら(1986)や伊禮ら(2008)の研究 によれば，平滑材に機械加工によって人工的に開けた穴（欠陥）がある場合，き裂は穴の影響を受けて屈曲しな がら進展すると報告している.

以上の観察結果より，未溶着部先端近傍の溶接欠陥は，き裂の進展方向に影響を与えていることが明らかとな った．しかしながら，溶接欠陥の影響により進展方向を変えたき裂は，その後の進展過程で早期に溶接欠皕の影 響を受けていないき裂面と同じ位置に戻ること，さらに，欠陥の影響を受けない section A, Fのき裂長さは欠陥の 影響を受けた section B, C のき裂長さと顕著な差が無い.つまり, section B, C は欠皕の影響を受けてき裂が屈曲し ているが，欠陥を超えた後は欠陥がない時のき裂前縁に揃っている．また，本試験体においては溶接欠陥数が多 くなく, このような未溶着部近傍の溶接欠陥の影響が試験体の疲労寿命に及ぼす影響は大きくないものと考える ことができる.
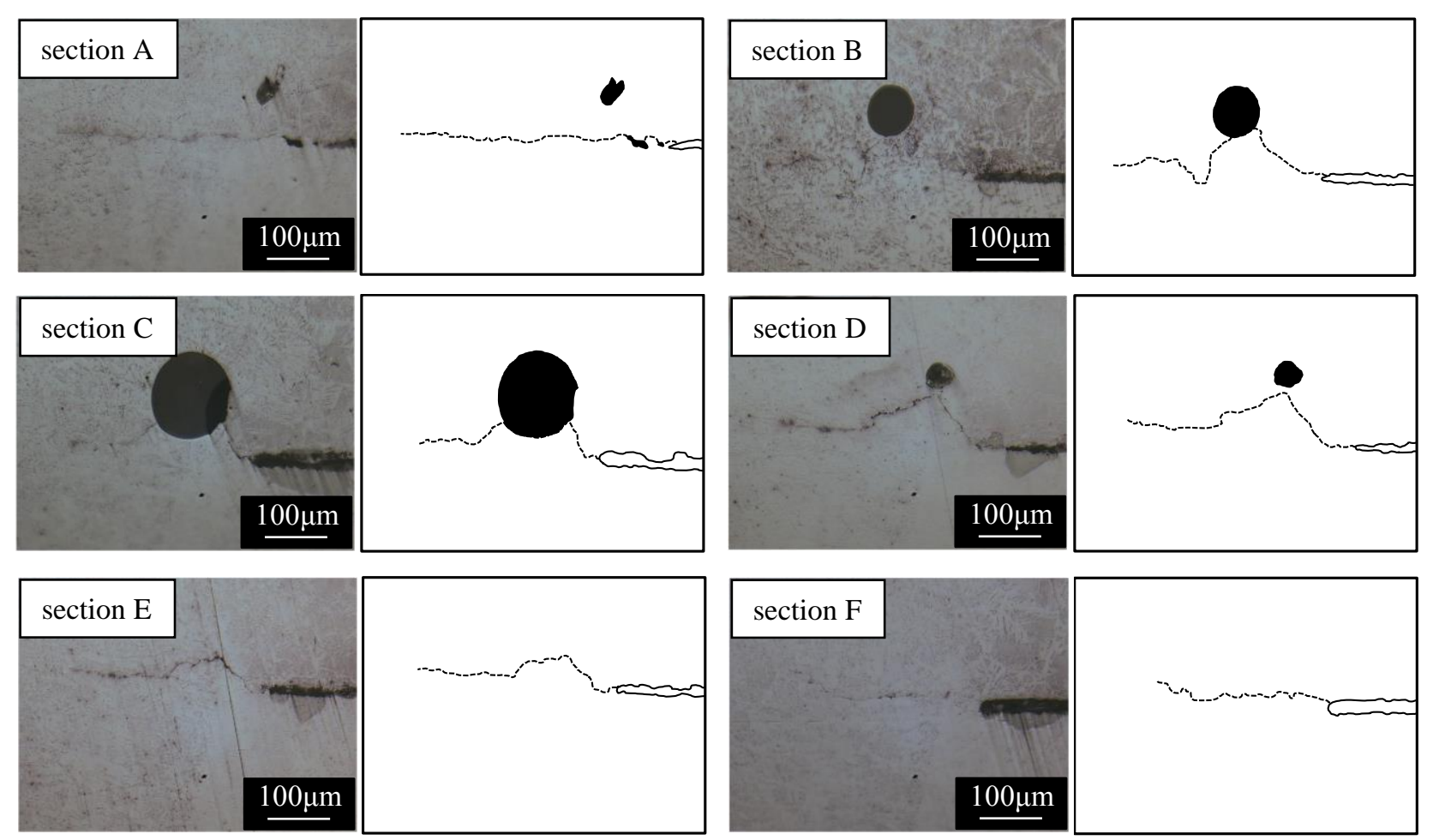

Fig.18 Crack propagation behavior near welding defect

\section{4. 結 言}

本研究では，板厚寸法，溶接材，溶接条件を実機と同一として製作した片側すみ肉溶接継手を用い，実機と同 等の負荷形式にて，溶接金属部内に発生，進展する疲労き裂を詳細に観察することにより，荷重伝達型片側すみ 肉溶接継手の疲労特性，および破壊メカニズムについて実験的検討を行った．未溶着部隙間を有する本試験体に ついて, 得られた結論を以下に示す. 
1. 本試験体は, 未溶着部先端より発生した疲労き裂が, 溶接金属部内を進展し最終破断を導く破壊形態を示し, 巨視的破壊形態に及ぼす負荷試験力振幅依存性は認められない.

2. 溶接金属部には複数の溶接欠陥が存在するが，これらの溶接欠陥はき裂発生起点にはならず，疲労き裂は未 溶着部先端から発生する.さらに，これらの溶接欠陥はき裂進展方向に影響を及ぼすものの，疲労寿命に及 ぼす影響は小さい。

3. 疲労き裂の三次元的観察より, 疲労き裂は全寿命の極初期に発生しており, 全寿命に対してき裂進展寿命が 支配的であることが明らかとなった。

4. 本試験体には複数のき裂発生起点が認められ, さらに繰返し数の増加に伴い発生した疲労き裂が合体しなが ら進展する挙動であることが明らかとなった。

\section{文献}

Bell, R., Vosikovsky, O. and Bain, S. A., The significance of weld toe undercuts in the fatigue of steel plate T-joints, International Journal of Fatigue 11 No.1 (1989), pp. 3-11.

Carpinteri, A., Brighenti, R., Huth, H. and Vantadori, S., Fatigue growth of surface crack in a welded T-joint, International Journal of Fatigue Vol. 27, Issue 1 (2005), pp. 59-69.

Chung, H.Y., Liu, S.H., Lin, R.S. and Ju, S.H., Assessment of stress intensity factors for load-carrying fillet welded cruciform joints using a digital camera, International Journal of Fatigue Vol. 30, Issues10-11 (2008), pp. 1861-1872.

藤原 敏, 宮園 高, 福田 収一, 疲労き裂進展経路の予知に関寸る研究 (第 1 報, 予備的検討), 日本機械学会 論文集 A 編 Vol.52, No.481 (1986), pp. 2139-2142.

伊禮 良樹, Anggit MURDANI, 国吉 和男, 真壁 朝敏, き裂進展挙動に及ぼすき裂先端近傍への穴加工とその 穴へのピンの打ち込みの影響について，日本機械学会論文集 A 編 Vol.74, No.741 (2008), pp. 706-712.

一般社団法人 日本鋼構造協会, 鋼構造物の疲労設計指針・同解説 (2012).

Kainuma, S. and Mori, T., A fatigue strength evaluation method for load-carrying fillet welded cruciform joints, International Journal of Fatigue Vol. 28, Issue 8 (2006) , pp. 864-872.

Kanvinde, A.M., Gomez, I.R., Roberts, M., Fell, B.V. and Grondin, G.Y., Strength and ductility of fillet welds with transverse root notch, Journal of Constructional Steel Research Vol. 65, No. 4 (2009), pp. 948-958.

Miki, C., Tateishi, K., Fan, H. and Tanaka, M., Fatigue strengths of fillet-welded joints containing root discontinuities, International Journal of Fatigue Vol. 15, Issue 2 (1993), pp. 133-140.

森 猛, 片面すみ肉溶接継手の疲労強度に対する溶接溶け込み深さの影響, 鋼構造論文集 Vol.10, No. 40 (2003).

森 猛, 貝沼 重信 荷重伝達型十字隅肉溶接継手・ルート破壊の疲労強度評価手法の提案, 土木学会論文集 I Vol. 501, No.29 (1994).

中込 忠男, 岡田 忠義, 李 建, 久保田 一男, 十字継手接合部の疲労強度に関寸る実験的研究, 鋼構造年次論文集 Vol.2 (1994).

Otegui, J.L., Mohaupt, U.H. and Burns, D.J., Effect of weld process on early growth of fatigue cracks in steel T joints, International Journal of Fatigue Vol.13, Issue 1 (1991), pp. 45-58.

一般社団法人 日本溶接協会 : 日本溶接協会規格(WES) (2011).

山田 健太郎, 金仁泰, 伊藤 健一, 作用応力に斜めな荷重非伝達型リブ十字すみ肉溶接継手の疲労挙動, 土木学会 論文集 I Vol. 682, No.56 (2001).

\section{References}

Bell, R., Vosikovsky, O. and Bain, S. A., The significance of weld toe undercuts in the fatigue of steel plate T-joints, International Journal of Fatigue 11 No1 (1989), pp. 3-11.

Carpinteri, A., Brighenti, R., Huth, H. and Vantadori, S., Fatigue growth of surface crack in a welded T-joint, International Journal of Fatigue Vol.27, Issue 1 (2005), pp. 59-69. 
Chung, H.Y., Liu, S.H., Lin, R.S. and Ju, S.H., Assessment of stress intensity factors for load-carrying fillet welded cruciform joints using a digital camera, International Journal of Fatigue Vol.30, Issues 10-11 (2008), pp. 1861-1872.

Fujiwara, S., Miyazono, T. and Fukuda, S., A study on the prediction of a fatigue crack growth path $\left(1^{\text {st }}\right.$ Report, A preliminary study), Transactions of japan society of mechanical engineers, Series A, Vol.52, No.481 (1986), pp. $2139-2142$ (in Japanease).

Irie, Y., Murdani, A., Kuniyoshi, K. and Makabe, C., Effects of drilling holes in the vicinity of crack tips and inserting pins into them on crack growth behavior, Transactions of japan society of mechanical engineers, Series A, Vol.74, No.741 (2008), pp. 706-712 (in Japanease).

Japanese Society of Steel Construction ed., Fatigue design recommendations for steel structures, Japanese Society of Steel Construction (2012) (in Japanease).

Kainuma, S. and Mori, T., A fatigue strength evaluation method for load-carrying fillet welded cruciform joints, International Journal of Fatigue Vol.28, Issue 8 (2006), pp. 864-872.

Kanvinde, A.M., Gomez, I.R., Roberts, M., Fell, B.V. and Grondin, G.Y., Strength and ductility of fillet welds with transverse root notch, Journal of Constructional Steel Research Vol.65, No.4 (2009), pp. 948-958.

Miki, C., Tateishi, K., Fan, H. and Tanaka, M., Fatigue strengths of fillet-welded joints containing root discontinuities, International Journal of Fatigue Vol.15, Issue 2 (1993), pp. 133-140.

Mori, T., Influence of weld penetration on fatigue strength of single-sided fillet welded joints, Steel construction engineering Vol.10, No.40 (2003) (in Japanease).

Mori, T. and Kainuma, S., A fatigue strength evaluation method for load-carrying fillet welded cruciform joints, Journal of Structural Mechanics and Earthquake Engineering Vol.501, No.29 (1994) (in Japanease).

Nakagomi, T., Okada, T., Gun, L. and Kubota, K., Experimental study on fatigue strength of cruciform welded joint, Steel construction engineering Vol.2 (1994) (in Japanease).

Otegui, J.L., Mohaupt, U.H. and Burns, D.J., Effect of weld process on early growth of fatigue cracks in steel T joints, International Journal of Fatigue Vol.13, Issue 1 (1991), pp. 45-58.

The Japan Welding Engineering Society ed., Welding Engineering Standard, The Japan Welding Engineering Society (2011) (in Japanease).

Yamada, K., KIM, I. and Ito, K., Fatigue behavior of inclined non-load-carrying fillet welded joints, Journal of Structural Mechanics and Earthquake Engineering I, Vol. 682, No.56 (2001) (in Japanease). 